\title{
Calcium, Metals and Nervous System in the Elderly
}

\author{
Yoshiro YASE \\ Division of Neurological Diseases, Wakayama Medical College, \\ Wakayama, Japan
}

Biologic processes in the aging of the brain and its pathologic alterations have been precisely investigated. Dementia, for example, is a most common symptom of the age-related central nervous system (CNS) function, and is the main symptom found in senile dementia and Alzheimer disease (AD). Although AD has long been considered as a case with an onset before age 65 , recent clinicopathological and biochemical studies indicated that $\mathrm{AD}$ and senile dementia are a single process, with a general agreement between them.

Morphological changes found in these are not specific and include decreased brain weight, neuronal loss, degenerative changes in the dendrite of pyramidal cells, increase of lipofuscin etc. Some characteristics of $\mathrm{AD}$, although being less marked in the elderly brain, are Alzheimer neurofibrillary tangle (NFT), senile plaque, granulovacuolar degeneration and Hirano body, which are also occasionally observed in amyotrophic lateral sclerosis (ALS) and Parkinson disease (PD).

Since the incidence of these degenerative diseases of the CNS tissue increases with age, aging factor(s) may be closely related to the degenerative process. Through the serial studies done on CNS degenerative diseases, the role of metals has been suggested as a pathogenetic participation of the degenerative process.

In this paper, the comparative study of metal behavior between these conditions is reported.

\section{Methods}

Metal content in the CNS tissue was determined by the elemental analytical methods, including neutron activation analysis (NAA), X-ray microanalysis (XMA) and particle induced X-ray emission (PIXE) methods, in cases with degenerative CNS diseases and controls. For the structural analysis, X-ray powder diffraction (XPD) and infra- red absorption spectrum (IRA) methods were used.

Content of various metals, which include calcium $(\mathrm{Ca})$, manganese $(\mathrm{Mn})$, aluminum $(\mathrm{Al})$, copper $(\mathrm{Cu})$ and phosphorus $(\mathrm{P})$ was mainly analyzed by NAA with or without simultaneous and nondestructive methods. Morphological distribution of these metals in the CNS tissue was investigated by XMA. For the screening search of metals to be detected, PIXE was used. In the identification of the chemical structure of these metals, XPD and IRA were adopted.

\section{Results}

1) Ca content by NAA. The average content of $\mathrm{Ca}$ was $252 \pm 86 \mathrm{ppm}$ (ranging 407 to 105 $\mathrm{ppm}$ ) in controls, ranging in age from 38 to 54, $381 \pm 176 \mathrm{ppm}$ in controls 80 years of age (ranging 723 to $87 \mathrm{ppm}$ ), and $405 \pm 105 \mathrm{ppm}$ (ranging 729 to $236 \mathrm{ppm}$ ) in ALS cases, ranging in age from 28 to 40 years. The $\mathrm{Ca}$ content in the aged control is much closer to that of ALS cases, although the range of its content varies remarkably from 87 to $723 \mathrm{ppm}$ in different localizations (Table 1).

2) Simultaneous determination of $\mathrm{Ca}, \mathrm{Mn}$ and Al by NAA. In aged control, not only $\mathrm{Ca}$ but also $\mathrm{Mn}$ and $\mathrm{Al}$ contents are higher than normal control, and close to those of ALS cases.

$\begin{array}{lccc} & \mathrm{C} 1 & \mathrm{C} 2 & \mathrm{C} 3 \\ \mathrm{Ca} & 231 \pm 77 & 295 \pm 190 & 222 \pm 47 \\ \mathrm{Mn} & 1.4 \pm 0.5 & 1.4 \pm 0.4 & 1.7 \pm 0.2 \\ \mathrm{Al} & 11.0 \pm 3.3 & 23.8 \pm 4.9 & 16.4 \pm 9.1 \\ & \mathrm{CA} & \mathrm{ALS} \\ \mathrm{Ca} & 466 \pm 179 & 434 \pm 124(\mathrm{ppm}) \\ \mathrm{Mn} & 2.4 \pm 0.5 & 1.3 \pm 0.2 \\ \mathrm{Al} & 33.2 \pm 16.2 & 33.7 \pm 18.5 & \end{array}$

In any of the ALS cases, there is the positive correlation in the content between $\mathrm{Ca}$ and $\mathrm{Al}$, or between $\mathrm{Ca}$ and $\mathrm{Mn}$. No correlation, however, 
Table 1. Calcium content of central nervous system tissue in amyotrophic lateral sclerosis and in normal and aged control cases.

\begin{tabular}{|c|c|c|c|}
\hline & $\begin{array}{l}\text { Amyotrophic lateral } \\
\text { sclerosis (ppm) }\end{array}$ & $\begin{array}{l}\text { Normal control } \\
\text { (ppm) }\end{array}$ & $\begin{array}{l}\text { Aged control } \\
(\mathrm{ppm})\end{array}$ \\
\hline Precentral & 371 & 216 & 518 \\
\hline Postcentral & 236 & 236 & 410 \\
\hline Frontal & 452 & 406 & - \\
\hline Parietal & 416 & 407 & 377 \\
\hline Insula & 379 & 249 & - \\
\hline Temporal & 412 & 395 & 275 \\
\hline Occipital & 387 & 343 & 447 \\
\hline Hippocampus & 506 & 233 & - \\
\hline Thalamus & 373 & 176 & 354 \\
\hline Caudate nucleus & 405 & 189 & 628 \\
\hline Capsula interna & 342 & 152 & 723 \\
\hline Globus pallidus & 366 & 201 & 172 \\
\hline Putamen & 289 & 191 & 87 \\
\hline Crus cerebri & 501 & 244 & 165 \\
\hline Substantia nigra & 352 & 105 & 342 \\
\hline Red nucleus & 469 & 200 & 284 \\
\hline Pons & 319 & 288 & - \\
\hline Medulla & 538 & 247 & 284 \\
\hline Spinal cord & 729 & 314 & 612 \\
\hline Cerebellum, gray & 379 & 332 & 422 \\
\hline Cerebellum, white & 293 & 170 & - \\
\hline Mean & 405 & 252 & 381 \\
\hline Standard deviation & 105 & 86 & 176 \\
\hline
\end{tabular}

was seen in any control case between the ages of 28 to 40 . But in the aged control group of 80 years, a positive correlation between $\mathrm{Ca}$ and $\mathrm{Al}$ was indicated.

3) Al content in $A D$ case by NAA. Average content of $\mathrm{Al}$ in the $\mathrm{CNS}$ tissue in $\mathrm{AD}$ cases showed $33.5 \pm 6.3 \mathrm{ppm}$, while controls $18.8 \pm 0.9$ ppm. Average Ca content in the CNS tissue of $\mathrm{AD}$ cases was $837 \pm 420 \mathrm{ppm}$ and in controls $131 \pm$ $47 \mathrm{ppm}$.

There is no significant difference in $\mathrm{Al}$ content in the CNS tissue between $\mathrm{AD}$ and aged controls, although $\mathrm{Ca}$ content is much higher in the $\mathrm{AD}$ cases.

$\begin{array}{ccc}\mathrm{AD} 1 & \mathrm{AD} 2 & \mathrm{AD} 3 \\ 787 \pm 212 & 1,350 \pm 439 & 1,013 \pm 202 \\ 24.8 \pm 4.5 & 42.5 \pm 25.6 & 32.2 \pm 8.7\end{array}$

$\begin{array}{cccc} & \mathrm{AD} 4 & \mathrm{C} 1 & \mathrm{C} 2 \\ \mathrm{Ca} & 197 \pm 43 & 124 \pm 37 & 138 \pm 34(\mathrm{ppm}) \\ \mathrm{Al} & 34.2 \pm 13.2 & 19.6 \pm 10.2 & 17.7 \pm 8.6\end{array}$

4) Metal analysis by PIXE. Trace elements detected by alpha particle excited X-ray fluorescence analysis of the cervical spinal cord from cases with ALS and controls were Al, Si, P, S, Cl, $\mathrm{K}, \mathrm{Ca}, \mathrm{Ti}, \mathrm{V}, \mathrm{Mn}$ and $\mathrm{Fe}$. The content of $\mathrm{Al}$, $\mathrm{Si}, \mathrm{P}, \mathrm{Ca}, \mathrm{Ti}, \mathrm{V}, \mathrm{Mn}$ and $\mathrm{Fe}$ was higher in cases with ALS than in controls.

The aged, however, showed a high $\mathrm{Ca}$ content, close to that of the cases with ALS, but other metals, usually found in high concentrations in cases with ALS, were not detected, as seen in Fig. 1.

5) Ca-Hydroxyapatite (Ca-Hap) by XPD and IRA. Metal studies conducted by XPD (Fig. 2) 


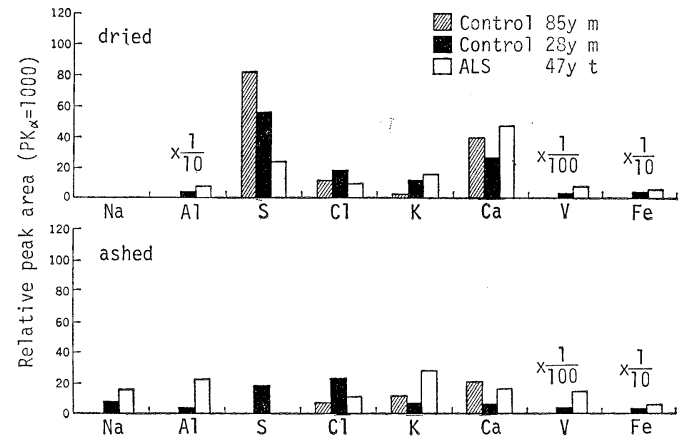

Fig. 1. $\mathrm{He}^{+}$elicited X-ray analysis (spinal cord).

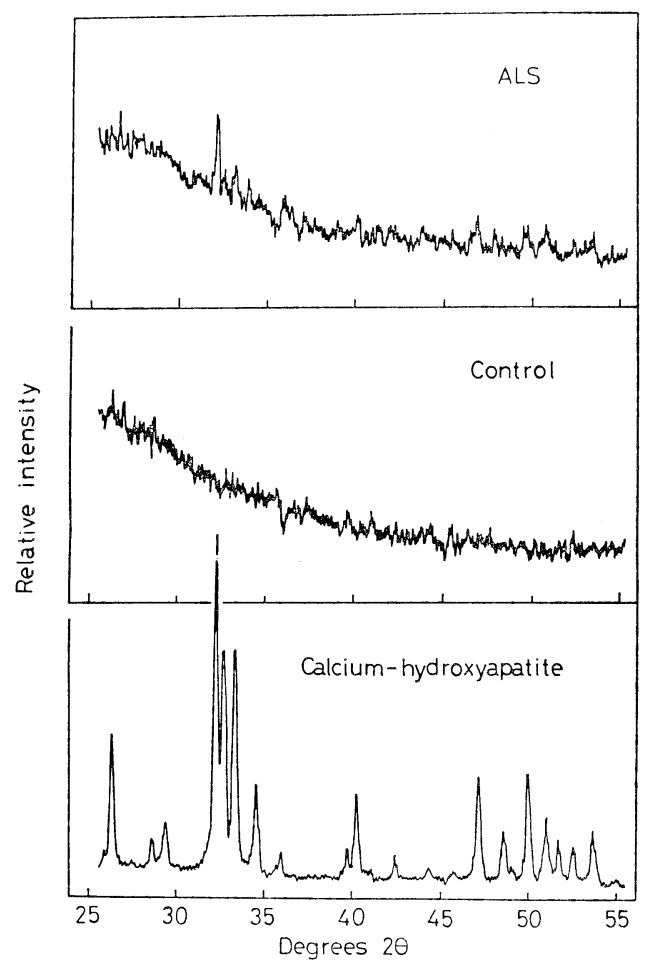

Fig. 2. Comparison of X-ray diffraction patterns of ashed cervical cord specimens of ALS and control cases, and calcium-hydroxyapatite.

and IRA (Fig. 3) suggest that Ca substances found in ALS cases exist as a form of Ca-Hap, substituted by other metallic ions such as $\mathrm{A} 1, \mathrm{Mn}$, etc.

Ca-Hap content in the brain and spinal cord in the ALS case (63 years, female) showed 317 $\mathrm{ppm}$ in the brain and $685 \mathrm{ppm}$ in the spinal cord, compared with $33 \mathrm{ppm}$ in the brain and $102 \mathrm{ppm}$ in the spinal cord of the control case (79 years, female). Content of Ca-Hap in the AD case also

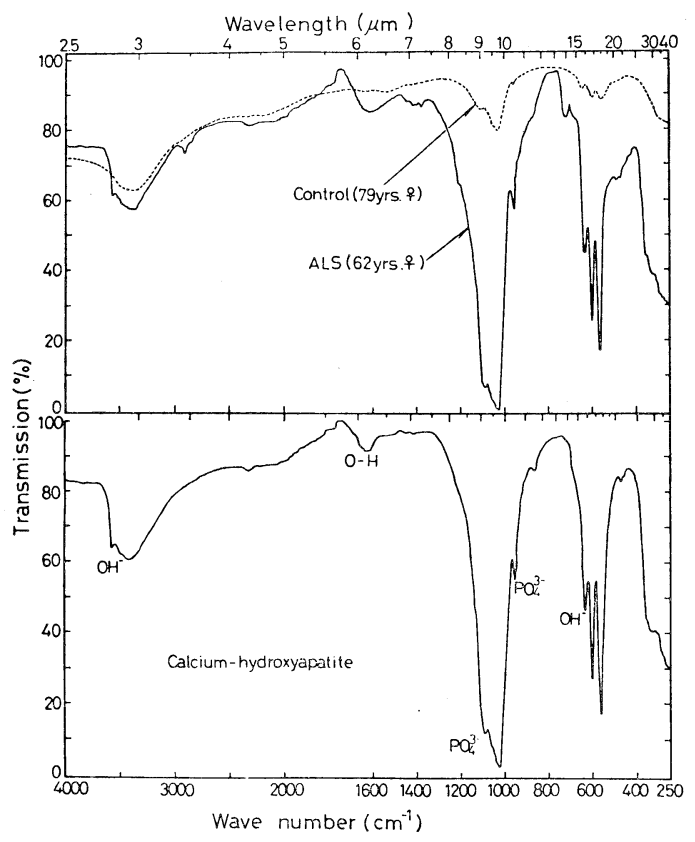

Fig. 3. Comparison of infra-red absorption spectra of ashed cervical cord specimens of ALS and control cases, and calcium-hydroxyapatite.

showed less than $100 \mathrm{ppm}$ in the brain.

\section{Discussion}

Apart from the neuropathological changes found in the aging process, metal behavior in the CNS tissue of the aged has not been well demonstrated.

Metals, especially toxic elements such as mercury, cadmium, lead, etc., usually accumulate in the body with age. This depositing tendency is also observed in the CNS tissue, which manifests various clinicopathological changes. There is, however, a wide variation in the content of different metal elements; for example, there is less $\mathrm{Cu}$ and $\mathrm{Zn}$ content in the CNS tissue, but more content of $\mathrm{Fe}$ and $\mathrm{Mg}$ with age.

In our serial studies of metal analysis, the content of $\mathrm{Ca}, \mathrm{Mn}$ and $\mathrm{Al}$ was higher in the aged CNS tissue than in normal controls. Ca content in the normal CNS tissue is usually 200 to 250 ppm, when determined by NAA, and increases to over $400 \mathrm{ppm}$ in the aged control group, as 80 years old. In the ALS case, Ca content corresponds to that of the aged, with a positive correlation between $\mathrm{Ca}$ and $\mathrm{Mn}$ or between $\mathrm{Ca}$ and A1. There 
was, however, no correlation in any normal control case. This was found only in the aged.

Increased Al content in the brain tissue in certain conditions have been reported by several investigators; in $\mathrm{AD}$ by Crapper et al. $(l)$, in dialysis encephalopathy by Alfrey et al. (2) and in the senile brain by McDermott et al. (3). We also reported increased content of $\mathrm{Al}$ with a positive correlation to $\mathrm{Ca}$ in the brain tissue of degenerative CNS disease cases, including ALS, Parkinson disease, Guam $P D$ and $A D$ (4). In the $A D$ case, there was a high content of $\mathrm{Al}$ in the CNS tissue, with a positive correlation to $\mathrm{Ca}$. This increased $\mathrm{Al}$ is diffusely distributed in gray and white matter, and basal ganglia.

The neurotoxicity of Al in animals has been clearly demonstrated; Al-induced neurofibrillary degeneration(NFD) was found using intracerebral (Klatzo et al. (5)), intraventricular (Yates et al. (6)) and subcutaneous (DeBoni et al. (7)) injection of Al salts, although the toxic mechanism is still obscure.

Al accumulation in the nuclear region and perikaryal cytoplasm of NFT-bearing hippocampal neurons was reported in ALS and PD cases in Guam (Perl et al. (8)), suggesting the association between intraneuronal $\mathrm{Al}$ and NFT formation.

A possible relationship between $\mathrm{Al}$ and NFD formation is indicated, but NFD, found as the component of the human NFT, is the paired helical filaments (PHFs), which are not the same as $\mathrm{Al}-$ induced NFD (Terry et al. (9)). Interestingly, there is a possible environmental reflection by $\mathrm{Al}$ exposure in ALS/PD changes with NFT formation in Guam cases, in which a high content of $\mathrm{Al}$ in the CNS tissue was found. A striking positive linear correlation between the number of NFTbearing hippocampal neurons and brain $\mathrm{Al}$ content, was observed in those Guam PD cases. These findings, together with the formation of Al-induced NFT in susceptible animals, stimulate further interest (10).

The question of how these metals deposit is also interesting. Simultaneous determination by PIXE detected high content of $\mathrm{Al}, \mathrm{Si}, \mathrm{P}, \mathrm{Ca}, \mathrm{Fe}$, etc. in the cervical spinal cord and frontal lobe samples of ALS cases. Coexistence of $\mathrm{Ca}$ and other metals, with their positive correlation in tissues and $\mathrm{Ca} / \mathrm{P}$ atomic ratio of 1.6 (11), strongly suggests the formation of a certain chemical compound of calcified substance, i.e., of Ca-Hap, because $\mathrm{Ca} / \mathrm{P}$ atomic ratio of $\mathrm{Ca}-\mathrm{Hap}$ is 1.67 . Related to Hap formation, $\mathrm{Mg}$ in $\mathrm{Mg} \mathrm{ATP}$, which inhibits the apatite production, may be substituted by Al, developing into Al-ATP and participating in apatite formation as an accelerator.

It is being confirmed by the structural analyses that the calcified substances in the CNS tissue of ALS cases are Ca-Hap, substituted by $\mathrm{Al}, \mathrm{Mn}$ and other metallic ions. The content of Ca-Hap in brain samples of ALS case showed over 100 ppm, but only $3 \mathrm{ppm}$ in the control. In the spinal cord, ALS cases showed over 200 ppm, but control was $500 \mathrm{ppm}$.

It is, therefore, assumed that, although the aged shows a high $\mathrm{Ca}$ content in the CNS tissue, this deposit of $\mathrm{Ca}$ differs from those in ALS cases which may exist as a form of Ca-Hap.

My gratitude is extended to the following collaborators: F. Yoshimasu, M.D. and M. Yasui, M.D., Dept. of Neuropsychiatry, Y. Uebayashi, M.D. and S. Yoshida, M.D., Division of Neurological Diseases, Wakayama Medical College; S. Iwata, Ph.D. and K. Sasajima, Research Reactor Institute, Kyto University, and Y. Mizumoto, Ph.D., Dept. of Science and Engineering, Kinki University; K.M. Chen, M.D. and D.C. Gajdusek, M.D., NINCODS, NIH.

\section{REFERENCES}

1) Crapper, D.R. et al. (1973): Science, 180, 511.

2) Alfrey A.C. et al. (1976): N. Engl. J. Med., 294, 184.

3) McDermott, J.R. et al. (1977): Lancet, 2, 8040.

4) Yoshimasu, F. et al. (1982): Folia Psychiat. Neurol. Jpn., 36, 173.

5) Klatzo, I. et al. (1965): J. Neuropathol. Exp. Neurol., 24, 187.

6) Yates, C.M. et al. (1976): Neuropathol. Appl. Neurobiol., 2, 131.

7) DeBoni, U. et al. (1976): Acta Neuropathol., 35, 285.

8) Perl, D.P. et al. (1982): Science, 217, 1053.

9) Terry, R.D. et al. (1965): J. Neuropathol. Exp. Neurol., 24, 200.

10) Yase, Y. (1984): in Neuromuscular Diseases, ed. by Serratrice, G., Rauen Press, New York, p. 335.

11) Mizumoto, Y. et al. (1983): Radioisotopes, 32, 551. 